Article

\title{
Leadership in Sustainability: Creating an Interface between Creativity and Leadership Theory in Dealing with "Wicked Problems"
}

\section{Renee Newman-Storen}

Centre for Research in Entertainment, Arts, Technology, Education and Communications (CREATEC), Western Australian Academy of Performing Arts, Faculty of Education and Arts, Edith Cowan University (ECU), Mount Lawley, WA, Perth 6050, Australia; E-Mail: r.newman-storen@ecu.edu.au; Tel.: +61-8-6304-6950

Received: 30 July 2014; in revised form: 29 August 2014 / Accepted: 1 September 2014 / Published: 4 September 2014

\begin{abstract}
Fundamental to Leadership in Sustainability, a course in the Masters in Sustainability and Climate Policy (coursework) offered through Curtin University Sustainability Policy (CUSP) Institute, is that the complexity, flexibility and vitality of sustainability are precisely why sustainability practitioners commit themselves to finding new and innovative solutions to complex problems. The course asks the student to "think differently" and to engage in debate that inspires and encourages creative thinking strategies for the planning and development of our cities and communities. This paper details what the course is about, how it is structured and what the connections are between creativity, sustainability and theories of leadership, arguing that strong and resilient leadership requires thinking differently in order to deal with "wicked problems" associated with sustainability.
\end{abstract}

Keywords: leadership; sustainability; creativity; creative thinking; collaboration

\section{Introduction}

In 2007, the Australian Government produced a paper, Tackling Wicked Problems: A Public Policy Problem, where the Australian Public Service was seen to be increasingly confronted with complex problems, referring to these issues as "wicked problems": the kind that challenge "governance structures, our skills base and our organisational capacity" [1] (p. 3). Wicked problems are at the heart 
of every debate, question, dilemma or value shift that faces today's sustainability practitioners, whether they may be city planners or work for an NGO, whether issues are relating to health, social welfare, the economy or the environment:

Wicked problems are characterised by social complexity: they cross the boundaries of APS agencies; they cross jurisdictional boundaries. Stakeholders (and experts) often disagree about the exact nature and causes of the problems and, not surprisingly, they disagree about the best way to tackle them [1] (p. 35).

This paper calls for greater research and reflection on the impact of creative thinking strategies in providing strong leadership in sustainability practice to deal with "wicked problems", including how might we plan better, more diverse, dynamic and ultimately more resilient cities and communities for the future by using creative thinking strategies. The bulk of this article reflects on the course, in particular the nature and role of the creative assessment, offered through Curtin University Sustainability Policy (CUSP) Institute, Leadership in Sustainability (LiS).

\section{The Workings of Leadership in Sustainability}

LiS has been offered internally and externally since 2009 predominantly as a unit in the Masters in Sustainability and Climate Policy (coursework) and as professional development for those looking to extend their skills. More recently, in 2012, LiS joined forces with Murdoch University so that their Masters and Undergraduate students in Sustainable Development could also enjoy what the course had to offer. The unit runs intensively over three days. The first two are lectures and interviews with sustainability practitioners, as well as setting up the practical component in creativity. Several hours are set aside to enable students to understand the value in creativity and for discussion regarding what was expected from them in the assessment. The final day is devoted to the exhibition, the group showing of the major creative project. The unit begins with an introduction lecture from Professor Peter Newman reviewing the field of sustainability by covering materials, such as a pioneering work by Schumacher [2], the Brundtland Report [3], World Summits, such as Rio+20 [4], and both rounds of the Kyoto Protocol [5,6], while allowing for some consideration of contemporary theories on leadership. This is followed by a lecture called Creativity, Leadership and Sustainability. This lecture largely informs this paper. The following content of the unit is comprised of interviews with leaders in the world of sustainability, or who we refer to as Sustainability Champions. The Sustainability Champions change from year to year, and the format is either a face-to-face, or live interview, or via a previously filmed interview from CUSP's film archive. The Champions are young and old, both male and female, and are people from professional practice in government, business and civil society. The interviewees are encouraged to speak of their personal and professional experience, and as a result, the interviews become stories that are candid and, at times, emotional. This is a profoundly unique component of the course. The assessment for the course will be discussed in detail later in the paper.

This paper essentially reviews the intersection between sustainability, leadership and creativity that is fundamental to the ethos of LiS. I firstly examine these concepts in not only an applied sense, but also in a philosophy of "thinking differently". Then, I will briefly look at some examples of environmental, land and sustainable art and artistic interventions on the urban landscape. Finally, I will 
detail the assessment component of the course and reflections, anecdotal and pictorial, on what we see as the success of the unit and the enormous potential for this kind of pedagogical "awakening". At the core of this course is the understanding that just as the integration between ecological, social and economic elements is inherent in the practice of sustainability, so creativity is a necessary element in bringing sustainability and leadership together.

\section{Creativity, Sustainability and Leadership}

This course is about thinking and doing, performing and behaving, differently; it argues that "sustainability requires change, and change requires leadership". The theoretical physicist David Bohm argues that the: "ability to perceive or think differently is more important than the knowledge gained" [7] (p. 172). Creative change, like that of sustainability, requires innovation, difference, adaptation and collaboration, and for this to happen, the course advocates that participants think of themselves as having the possibility to become creative change agents. This is not to say that more traditional top down leadership approaches are not relevant or are not creative, but rather, that other more complex and adaptive methods of leadership engagement do require thinking and acting "differently" in order to address similarly complex problems, and thus, this notion of thinking and acting "differently" is an inherently creative concept. This is similar to the approach of design thinking, the movement in design that enlists interdisciplinary collaborations to listen to stakeholders, define problems, identify gaps, develop appropriate research and find adaptive and innovative solutions.

Innovators love creating an idea and are constantly trying to invent new things to improve already existing products and services. When people are creating ideas, they get excited about it, take ownership and make commitments. They do everything possible to make sure the concept can become a reality that others appreciate. When the creation process is performed by a team, the effort can be magnified, and the energy is multiplied. For this reason, we consider co-creation as a crucial aspect in the complex socio-technical field of design thinking in action [8].

This approach might also be considered to be similar to Edward de Bono's six thinking hats used in team problem solving. The various coloured hats are the thinking strategies you wear in order to be effective in a problem solving situation; the information hat, the devil's advocate hat, the hat that identifies feeling and instinct, another for creative thinking and new ideas, another for optimism and the sixth, for managing the situation [9]. He also coined the term "lateral thinking", which he sees as "formal and deliberate creativity" [10] (p.1059). In New Thinking for the New Millennium, de Bono speculated that explosions in science and technology throughout modernity may have been at the neglect of advancement in human behaviour, and perhaps, a shift from the thinking of "what is" could be replaced with "what can be", thus adopting a more hopeful vision of resilience in the face of present and future problems [11]. LiS approaches the notion of creativity and creative thinking as the capacity to bring together various approaches to problem solving and visioning for the future; we need energised, active, practical and meaningful decisions and solutions made for an increasingly complex world.

- At the heart of the course are the principles that there are several essential characteristics of creativity; creativity at its core is making new: a new thing, an original concept, a novel process or a different association of what already exists; 
- Creativity involves critical and lateral thinking; dissecting and analysing established convention, while creating new original thought, processes and practices;

- Creativity involves story-telling (the narrative from which the creation emerges), and stories cannot be removed from a social/economic/historical context;

- A critical and dynamic aspect of creativity, and of art, is its political and ethical potential. In the arts, being able to represent and undermine inequity, the artist is able to expose what is often only whispered or strangled. Creativity can represent empowerment and encourage social change.

Creative thinking, as well as leadership and sustainability, requires us to look at the whole system and not just an individual element or unit to find new and novel ways of doing and creating. Joseph Jaworski argues: "if individuals and organizations operate from the generative orientation, from possibility rather than resignation, we can create the future into which we are living, as opposed to merely reacting to it when we get there" [12] (p. 182). Similarly, the inspirational performance maker and political activist, Augusto Boal, argued that: "Theatre is a form of knowledge; it should and can also be a means of transforming society. Theatre can help us build our future, rather than just waiting for it" [13] (p. xxxi). Note the similarity in argument between Jaworski and Boal; the desire to shape and map out the future we want, rather than waiting for the future to happen to us. Could we not also ask the same of sustainability, or for effective leadership, or creative thinking processes? This requires thinking differently and being immersed in possibility, to be an active and generative creator. Jeneatte Winterson writes: "I do not think of art as Consolation. I think of it as Creation....art makes it possible to live in energetic space" [14] (p. 114). Creativity is creation, and LiS argues that this is at the core for successful sustainability leadership.

\section{What Do Creativity, Leadership and Sustainability Share?}

In answering this question, the following might be considered:

- All three are conceptual processes, as well as practical;

- All three benefit from a trans-disciplinary approach: in dealing with complex problems, there is often a need for seemingly divergent sets of logic to come together as a system;

- All three discover moments of disruption where the status quo is disturbed;

- Sustainability matters not because it is "right" or because it makes sense both as a business case and in a risk-adverse climate, but because it is an engaged and innovative conversation with a wilful change of behaviour;

- Change is the creation of something new, something that came before being made different; thus, change not only requires creativity, but also, change is a form of creativity;

- Leadership is the bridge between creativity and sustainability. To bring forth sustainable practice and process, we need to become creative change agents or what Bernard Bass and Ronald Riggio might refer to as transformational leaders [15].

Another principle of LiS is the belief that what is required of successful and meaningful leadership in sustainability is a dynamic, flexible and resilient approach to the planning of our cities and communities. This requires creativity as a practice and philosophy, because sustainability and leadership require thinking and acting "differently", laterally and cooperatively and to challenge or 
reinforce values, ethics and behaviours. There are certain principles that go hand-in-hand in this kind of thinking. Predominantly, sustainability practitioners have to be prepared to engage in an interdisciplinary manner and understand the values and desires of others. To do this requires leadership, to be actively engaged in change and to listen to the people who want it and to the people who are afraid of it. To be a leader in sustainability, in its obscurity and instability, is inherently transformative, because we invite a space for the telling of stories, we ask for reflection on what works and what does not, what needs to change and what does not need to change and what needs to be celebrated.

Sustainability requires a shift in thinking; whether this is a shift away from a top-down leadership organisational structure or the integration of a whole systems approach to designing, planning and implementation of sustainability-orientated strategies. To be a leader in sustainability - in local government, for an $\mathrm{NGO}$, a development plan, a transport initiative or policy-requires fully understanding that every unit, every element to what you are doing at that point in time is interconnected, and, hence, every solution requires an integrated creative and innovative solution; even if the solution is obvious, its pathway might be fraught and complex. Bob Doppelt argues that: "Few leaders grasp the deep-seated paradigm shift inherent in sustainability" [16] (p. 16). In addition, creativity in relation to sustainability and in the creation of something new requires the acknowledgement of difference and the unique stories linked to place, history and narrative that every individual and every community has. Thus, leadership in sustainability, both the work itself, as well as the course we teach, is about identifying how to problem solve through collaboration and deliberation and, by doing so, create new ways of thinking, acting and behaving.

\section{Art and Sustainability}

It should seem no surprise that if we are to talk of creative thinking strategies, of becoming creative change agents, that pedagogically, we would want to also confront how the arts can intervene in sustainability issues. The arts have always been an avenue for social commentary and social action. If we were to take the connection between art and sustainability literally, there are several streams of artistic practice useful in this context: environmental art, land art and sustainable art and artistic interventions in urban space. Beth Carruthers is a Canadian research and curator who specialises in the connection between art and sustainability, and she suggests that: "The arts can facilitate a process of learning through the engaged sense, bypassing conditioned patterns of thinking and allowing other ways of knowing to come forward, at times subtly, at times overwhelmingly" [17] (p. 5).

Environmental art can be seen as the use of the environment/location as the object of art and not just merely an art object or as specifically concerning natural landscape and ecological and environmental concerns. The futurists of the early twentieth century (with their carefully calculated use of space) and the surrealists in the 1930s and 1940s were the precursor to what is known today as "environments" or the performance art form that emerged in the 1960s. These early works included Marcel Duchamp's piece at the First Papers of Surrealism exhibition, New York, in 1942, involving several kilometres of carefully constructed string [18]. Yves Klein's The Void in Paris in 1958 [19] gutted an exhibition space and left nothing but a cupboard. At opening night, 3000 people turned up to an empty room. Two years later, the artist, Arman, responded to The Void with Fullness (1960) by filling the same gallery with waste, transforming the space into an enormous dustbin [20]. 
Around the same time, changes to concepts of performance-what is it, what can it be, where should it be housed-meant that site-specific performance and visual arts-based installations were being developed: Allan Kaprow's "happenings" with Jim Dine, Robert Whitman and Claes Oldenburg involved a live performance that just "happened" [21]. Edward Kienholz used found and discarded objects to make installation [22]. George Segal [23]created life-sized figures depicted in relatable scenarios, thus drawing attention to space and place, and the optical nature of space was investigated by kineticist artist, Jesús-Rafael Soto [24]. Still in operation since 1980 is Walter De Maria's New York Earth-Room [25], where 3600 square feet of gallery floor space is covered with 280,000 pounds of earth, and Ant Farm - an avant-garde architecture, graphic design and environmental design collective-were most well-known for Cadillac Ranch, which was an installation in Amarillo, Texas, that used a variety of Cadillac's (representing the evolution of the car) half buried at angles that corresponded to the Great Pyramid of Giza in Egypt [26].

Arts projects that specifically link to the natural environment in form and content, whatever that may be, play with the concept of how the natural environment might frame art and how art might also raise awareness of the environment. Land art began in the 1960s as a way in which to reinterpret the natural world as both the subject and object of art and involved large sculptural pieces incorporating the landscape as a way to find a new way to talk about the land in art. There are necessary questions for this form, including the man-made colonisation of the natural environment for the creation of art works, yet nevertheless, land art used the landscape to reframe our understanding of nature. Alan Sonfist, over a period of 10 years, created a living art piece on the corner of West Houston and LaGuardia streets in Greenwich Village called Time Landscape [27]. It remains a lush garden put aside for the people, but was, in fact, in 1965, meticulously designed using only what was native to the Manhattan area in pre-colonial times. Time Landscape is a lasting legacy of a commitment to engaging art and the environment in one continual exchange.

"Sustainable art" can be seen as either the art project itself being sustainable in its material form or the subject of the art raising sustainability principles and/or problems. Indicative of this form was the "social sculpture" of German artist, Joseph Beuys. In 1982, as a way to further his life-long commitment to investigating the ways in which art could contribute to a "social revolution", he began his 7000 Oaks-City Forestation Instead of City Administration in Kassell, Germany [28]. Beuys, joined by community members, planted 7000 oak trees throughout the city with a solid stone marker at the base of each tree. In consultation with the local government, schools and community groups, the project initiated a debate about public space, community collaboration, artistic expression and environmental awareness. The project was completed in 1987, with the last tree planted by his son one year after Joseph's death and marked the continued legacy of a philosophy of bringing social change, ecological awareness and art together. There have been several homages to this all over the world, including in New York.

Sometimes, the dialogue between landscape (natural and urban) and art manifests in asking the viewer to observe an unfamiliar space in a different context or a familiar space differently: Antony Gormley, a British artist, created a series of wrought iron installation pieces on Lake Ballard in the Goldfields, Western Australia [29], and more recently, in New York, drawing our attention to the expanse of the desolate salt lake or the urban jungle of New York City [30]. Andy Goldsworthy, the Scottish painter, sculptor, photographer and environmentalist, has created similar site-specific work [31]. 
Christo and Jeanne Claude collaborated on work spanning over 40 years, producing extraordinary landscape art, including wrapping the Reichstag in fabric, encouraging the spectator to view the building in a completely new and significant way [32]. Wildworks is a U.K.-based company that makes "landscape theatre-large scale spectacular performances and artworks that are not only site-specific, but people-specific, and grow out of their locations: quarries, cliffs, harbours, derelict industrial sites, castles, empty department stores" [33]. In Australia John Stubley has created The Centre for Social Poetry [34] and was involved in the Zuccotti Square Occupy Wall Street Movement [35], which arguably, in its use of social network media, was, at a time, a highly creative space for engaged activism, while Rachel West and Strategic Creativity at Work offer performance, social innovation and design thinking and have been known to bring the circus to engineers and improvisation to hydrology [36].

Recently, I have engaged in a creative dialogue with Dr. Ryan Reynolds at the University of Canterbury in Christchurch, New Zealand, who is a founding member of the arts organisation, Gap Filler [37]. In the twisted roads and rubble of buildings left after the 2010 and 2011 earthquakes in Christchurch, there seemed, from a distance, little hope in negotiating an urban clean up, let alone an imagining for a renewed city. The Gap Filler Arts Initiative was begun by a group of Christchurch residents who were struck by the desire to take disused and semi-destroyed spaces, where $60 \%$ of the city centre was destroyed after the 2010 and 2011 Christchurch earthquakes, through various arts-based practices. What strikes me, though, is that Gap Filler is not so much a community arts group, as it is a movement, a facilitator of an urban mobilization; a galvanizing of public engagement and interaction in place making to reimagine the city. On an urban wasteland, they placed a commercial fridge filled with books with a small yellow brick path leading to it. Inside the fridge is a sign that read "take a book, leave a book". In over two years, it has only been vandalised once, and the fridge is constantly used. Hundreds of similar fridge libraries now exist across the city. There is also something very special about the cycle cinema playing old movies powered entirely by a system of specially designed power sites that fit ten bikes, ridden by the audience. Gap Filler embraces the transformative and experimental and, in doing so, just might happen to map out the city the people of Christchurch want to live in.

Anything is possible once one is able to view something, someone or somewhere differently to how one once did. This is both art, and it is sustainability thinking. However this different thinking is done, there are unique and wonderful ways to see the intersection of the land and art; of reclaiming old disused space, the stimulation of an awareness of new space, of reusing materials, changing behaviour or public space used and enabling public space to been seen differently. This concept is at the basis of place activation and place making. This is somewhat reminiscent of the Hypothetical Development Organisation (HDO), a group created by Rob Walker, Ellen Susan and G.K. Darby in the USA, that "commissions, prints and posts fantasy signage not only as a means of provoking interest in abandoned sites around New Orleans, but also as a way to generate an alternative narrative for the city" [38]. Nimble Fish is a U.K.-based arts company that creates "high-quality, arts-led happenings that foster social change" [39], working on many projects, including with school children in Lithuania.

In Athens, the birthplace of democracy, where the city (and country) is struggling to cope after the Global Financial Crisis, people are finding new and unique ways to speak back. In 2005, a performance piece, called Secret Locations, took one audience member at a time on a journey through the city, where the audience was asked to look out for clues, and 25 actors "ghosted" the area, so that 
they might find new ways to look at an ancient, and in certain areas, a decaying city. In another more recent project, Hypatia Vourloumis and Gigi Argyropoulou took to the streets in Athens and, in run-down areas, posted a temporary sign (a form of ephemeral graffiti) that read "potential" (in Greek). In works like these, there is a strong political and ethical argument that is similar to that of sustainability, because these leaders ask what are the needs and wants of the people, the polis, and citizens would and should be allowed to talk back. It is this kind of inscription in the urban landscape, a visioning of a future, which in some way is almost more important than actual transformation. Perhaps an artistic intervention, such as one noted above, will struggle to find lasting impact, and yet, it is precisely the ephemerality and the unquantifiable nature of how art engages the spirit of an individual and a community that is the greatest significance of artistic practice. These are works that are ephemeral, non-transportable, temporary and non-commercial and completely draw attention to meaning made through the materiality of space, of the environment within which we, and the art, exist.

\section{The Assessment}

The assessment for students from CUSP is divided into a participation grade, a creativity project and an essay. When Murdoch joined, this also included an exam for undergraduates and a text review for postgraduates. This section will detail only the essay and the creativity project. The essay is 3000 words and asks students to briefly describe one example of sustainability leadership that they have been involved with or know about (e.g., a process to promote a new sustainability policy, innovation or project in an organization or broader institution) and to describe initial objectives, the roles of key leaders and the key contextual factors. Their example is contextualized from the perspective of leadership theory and is analysed in relation to what the student thought worked, what did not work and what they would do differently to improve the leadership process if a similar situation were to occur in the future.

The Creativity Project is the most challenging and, quite possibly, the most rewarding element in the course. I have found students struggle, but ultimately triumph with the task. Guided by the principle that creative work is inspired by what can be seen and heard and what is directly experienced, the students firstly ask themselves how change can be affected through their personal or professional life in a way that involves principles of sustainability and leadership theory/practice. Secondly, they find a creative response in form and content that expresses this change. Third, there is the submission of a short explanation of the reasons behind this choice and the outcomes of artistic decisions, and finally, there is an exhibition of the final pieces. Weighting of the project is given predominantly to the strength of the idea and the reflective response, with less weighting given to the aesthetic representation itself. This is because the task is to think and behave creatively, without censure, and not to produce "beautiful" art.

The goal of the creativity project is for the students to take a sustainability issue, apply it to their life and look at it creatively, asking how can they affect change in their personal and professional life in a way that involves principles of sustainability and leadership theory/practice? Furthermore, they are asked to think about behavioural change and how notions of leadership impact changes in behaviour. Their creative response that expresses this change could be a song, poem, painting, sculpture, collage, film or blog, for example. It is imperative that everyone is able to show that they can apply the 
literature and concepts surrounding sustainability, leadership theory and creative thinking in relation to notions, such as emergence, adaption, servant-hood, complexity theory and systems analysis. It is equally important to compose a creative response that creates and reflects behavioural change and how notions of leadership impact changes in behaviour.

Over the last few years, LiS has had many different creativity projects. For example, a student created an interactive webpage/blog about how he made a planter box of mint, which he then supplied to a local café. The course has seen paintings, collages and sculptures. One student created a sculpture from the rubbish she had accumulated over a month; and another student brought in a loom, and we watched him create a thread from wool as a metaphor for complexity leadership theory.

In 2013, there were two community garden projects; one for an entire street that brought the neighbours together, contributing various things to the project, in the spirit of community, still evident today through periodic sundowners in the street. Another student, a mother of two young children, reused an old fridge, turning it into a worm farm, reconnecting with her family and the dirt in a way that then led to her reducing her energy use and spilling over into an ethical shopping program for her whole family. Another student created a wall piece representing a puzzle made from recycled objects, which was an artistic representation of a series of conversations she had on her porch drinking tea with her partner (see Figure 1 below). They changed light globes, altered their water and energy consumption and planned to transform their double car port into a garden. A year later, the behavioural changes have stayed, even if the garden is a long way off. However, she still feels that it was the conversation that was the most important shift.

Figure 1. Recycled objects as a wall piece printed with permission by the student for Leadership in Sustainability, 2013.

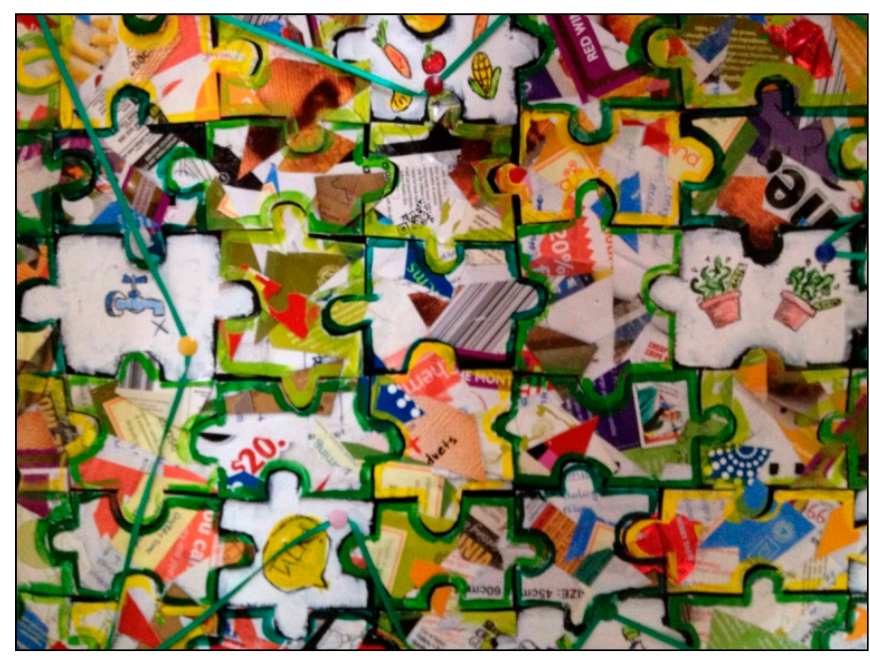

In 2013, a student who was raised on a farm and was most concerned about food security created two photographs depicting a couple seated eating in a field of wheat and another with the same couple in typical "business people" clothes complete with stiletto shoes shearing sheep; this was a beautiful commentary on the importance of acknowledging the source of our food and clothes. In the same year, a student created seed bombs, beautifully designed as actual bombs and some as clay pods, and she left them at various cafes, encouraging people to scatter everlasting flower seeds wherever they wanted to see something beautiful. 
In 2012, a student created an extraordinary splatter painting (see Figure 2) and filmed the process. Another student made a bike rack from scratch; having never welded in her life. In the same year, a series of seedlings and saplings were left in places you would not expect to find plant life, including on the bookshelves of Murdoch University library, along with a sign asking people to take them home and grow them (see Figure 3).

Figure 2. Splatter painting printed by permission by the student for Leadership in Sustainability, 2012.

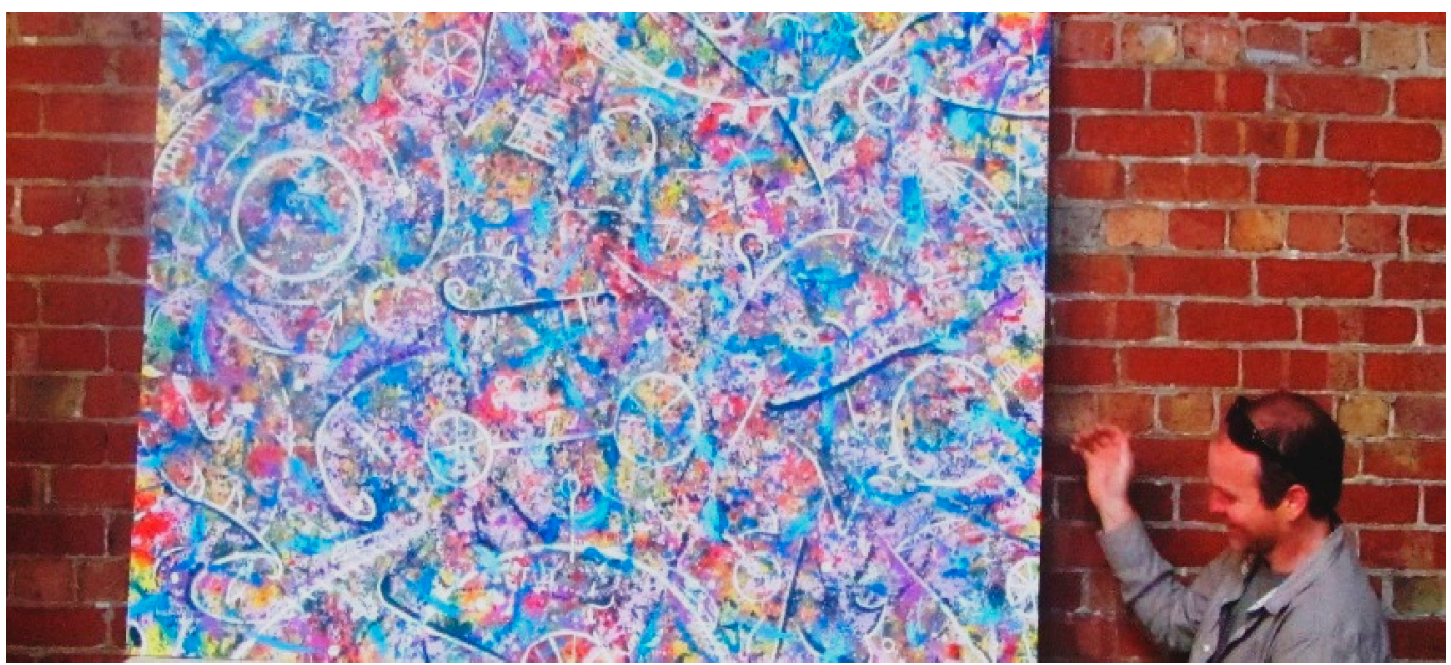

Figure 3. Grow me! Printed by permission by the student for Leadership in Sustainability, 2013.

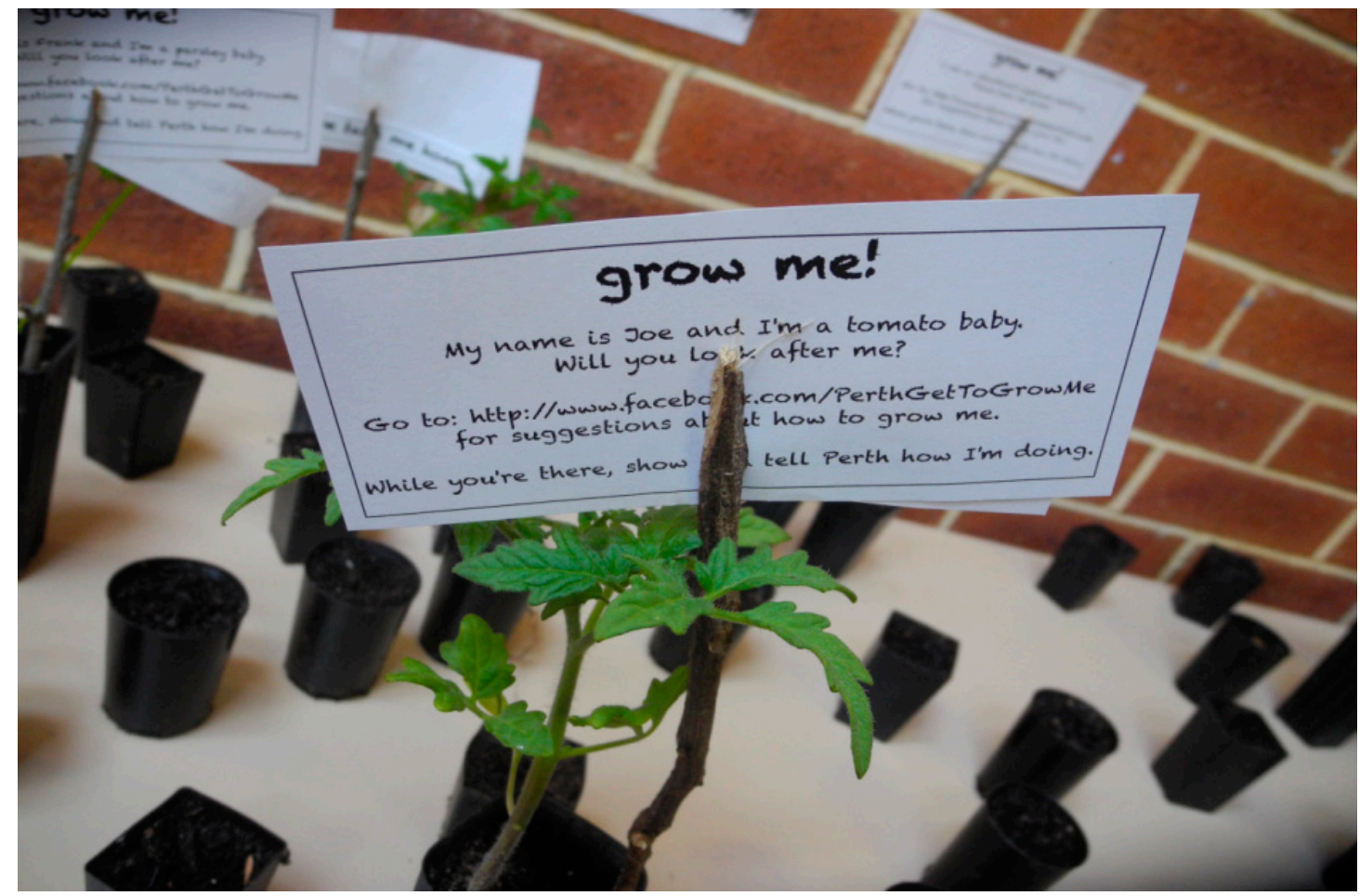

At three o'clock in the morning, one student found herself running through the disused and vacant sites of the port city, Fremantle, the police leaving her alone, when they realized she was only plastering paper posters with the word "possibility". In 2011, a student shared a story about how she 
had her neighbours and family over for dinner one night, where they decided to build a small community garden. This occurred while the class ate bread dipped in olive oil gifted from her neighbours and listened to an audio playback of the actual dinner party. It was a performance of a different kind. That same year, another participant spoke of how he struggled to think of what he would create for his project, but he did know that he wanted to make contact with his neighbours. He had no expectations other than an exchange of pleasantries, but by the end of the week, they had given each other a spare set of keys in case of an emergency. This turned out to be fortuitous, as the following week, his elderly neighbour fell over; but she was able to call him, and he was able to use the key to get into her home and help her. The images he used to represent this experience were of people he thought were brave and joyful. What I argue is that these projects may just be the beginning of a change that is much bigger than the art form itself, and I see each project as an act of storytelling; each participant is contributing their story to the wider stories of the larger community. Leadership in each instance can be seen to be a mix of adaptive and enabling leadership styles [40], wherein each participant enacted some sort of change in their life, which led to both an artistic response and a wilful change of behaviour.

\section{Conclusions}

Fundamental to LiS is that the complexity, flexibility and vitality of sustainability is precisely why we commit ourselves to such ideas, practices and ethics and that debate inspires and encourages sustainability practitioners and artists alike, because these practices are not mutually exclusive. This article is in no way an exhaustive analysis of leadership theory as it relates to "wicked problems" associated with sustainability; however, it does reflect upon one approach to a pedagogical alliance with sustainability, creativity and leadership. Sustainability, creativity and collaborative, strong and resilient leadership require thinking differently if we are to deal with "wicked problems" and embrace the uncertainty of our future. I remind the students that affecting change might not come easily (in their practice, as well as in the course), but what matters is thinking differently, and to do this is to encourage a paradigm shift. Sustainability requires sensitivity to difference and, essentially, at the heart of creativity, sustainability, and any concept of leadership requires telling stories; the stories of our people, of our land and of our cities. These stories have to be treated with care, but also with great energy and commitment, and as a method and a practice for today and the future, sustainability and strong leadership is the celebration of possibility. The stories that are literally told from the sustainability champions during LiS and what is evoked in the creativity project celebrate what it takes to be creative innovators, to be change makers.

\section{Acknowledgments}

This author acknowledges the wonderfully creative contributions of the students themselves, whose works have inspired this paper.

\section{Conflicts of Interest}

The author declares no conflict of interest. 


\section{References and Notes}

1. Australian Public Service Commission (APSC). Tackling Wicked Problems: A Public Policy Perspective; APSC: Canberra, Australia, 2007.

2. Schumacher, E.F. Small Is Beautiful: Economics' as if People Mattered; Harper and Row: New York, NY, USA, 1973.

3. United Nations. Report of the World Commission on Environment and Development (WCED): Our Common Future; WCED, Brundtland Commission: Stockholm, Sweden, 1987.

4. United Nations. In Rio +20 , Proceedings of the United Nations Conference of Sustainable Development (UNCSD), 20-22 June 2012, Rio de Janeiro, Brazil; United Nations: Rio de Janeiro, Brazil, 2012.

5. United Nations. Kyoto Protocol Round 1; Framework Convention on Climate Change: Kyoto, Japan, 1997.

6. United Nations. Doha Amendment to the Kyoto Protocol (Kyoto Protocol Round 2); Framework Convention on Climate Change: Doha, Qatar, 2012.

7. Jaworski, J. Synchronisity: The Inner Path of Leadership; Berrett-Koehler Publishers: San Francisco, CA, USA, 1996.

8. Meinel, C.; Leiger, L. Design Thinking Research. In Design Thinking Research: Studying Co-Creation in Practice; Plattner, H., Meinel, C., Leiger, L., Eds.; Springer: Heildelberg, Germany, 2012.

9. De Bono, E. Six Thinking Hats; Penguin: London, UK, 2000.

10. Powell, S. Spotlight on Edward de Bono. Manag. Decis. 2007, 45, 1058-1063.

11. De Bono, E. New Thinking for the New Millennium; Penguin Books: London, UK, 2000.

12. Jaworski, J. Synchronisity: The Inner Path of Leadership; Berrett-Koehler Publishers: San Francisco, CA, USA, 1996.

13. Boal, A. Games for Actors and Non-Actors, 2nd ed.; Routledge: London, UK, 2002.

14. Winterson, J. Art Objects: Essays on Ecstasy and Effrontery; Johanthon Cape: London, UK, 1995.

15. Bass, B.; Riggio, R. Transformational Leadership; Lawrence Erlbaum Associates: Mahwah, NJ, USA, 2006.

16. Doppelt, B. Leading Change toward Sustainability: A Change-Management Guide for Business, Government and Civil Society; Greenleaf: Sheffield, UK, 2003.

17. Carruthers, B. Mapping the Terrain of Contemporary EcoART Practice and Collaboration: Academic Paper; Canadian Commission for the United Nations Educational, Scientific and Cultural Organization (UNESCO): Vancouver, BC, Canada, 2006.

18. Marcel Duchamp, his twine, and the 1942 First Papers of Surrealism Exhibition, Public Art Installation in Philadelphia Museum of Art.

19. Le Vide (The Void). Sculpture, Iris Clert Gallery, 1958.

20. Arman. Fullness. Public Art Installation, Galerie Iris Clert, 1960.

21. Kaprow, Allan. Available online: http://www.theartstory.org/artist-kaprow-allan.htm (accessed on 2 September 2014).

22. Keinholz, E. Available online: http://www.beatmuseum.org/kienholz/edkienholz.html (accessed on 2 September 2014). 
23. Segal George. Available online: http://www.segalfoundation.org/about_bio.html (accessed on 2 September 2014).

24. Soto: The Houston Penetrable. Available online: http://www.mfah.org/exhibitions/past/jesusrafael-soto/ (accessed on 2 September 2014).

25. De Maria, W. New York Earth-Room, installation, Dia Art Foundation, 1968, 1974, 1977.

26. Ant Farm. Cadillac Ranch, Public Art Installation, Amarillo, Texas, USA, 1974.

27. Sonfist, A. Time Landscape, Public Art Installation, Manhattan, New York, USA, 1965.

28. Beuys, J. 7000 Oaks, Public Art Installation, Dia Art Foundation, 1982.

29. Gormley, A. Inside Australia, Public Art Installation, Lake Ballard, Menzies, 2002.

30. Gormely, A. Event Horizon, New York, Public Art Installation, New York, 2010.

31. Andy Goldsworthy Digital Catalogue. Available online: http://www.goldsworthy.cc.gla.ac.uk/ (accessed on 2 September 2014).

32. Christo and Jeanne-Claude. Available online: http://christojeanneclaude.net/ (accessed on 2 September 2014).

33. Wildworks. Available online: http://www.wildworks.biz/ (accessed on 18 September 2013).

34. The Centre for Social Poetry. Available online: http://socialpoetry.net/about/ (accessed on 20 September 2013).

35. The High Water Mark of Occupy Activity. Available online: http://occupythefuture.org/2012/ 01/24/the-high-water-mark-of-occupy-activity/ (accessed on 20 September 2013).

36. Strategic Creativity at Work. Available online: http://strategiccreativityatwork.com.au/about/ (accessed on 20 September 2013).

37. Newman-Storen, R.; Reynolds, R. Conversations over the Gap. Perform. Res. 2013, 18, 47-53.

38. The Inventionist Toolkit. Available online: http://designobserver.com/ (accessed 19 September 2012).

39. Nimble Fish. Available online: http://nimble-fish.co.uk/what-we-do/ (accessed on 20 September 2013).

40. Uhl-Bien, M.; Marion, R; McKelvey, B. Complexity Leadership Theory: Shifting Leadership from the Industrial Age to the Knowledge Era. Leadersh. Q. 2007, 18, 298-318.

(C) 2014 by the author; licensee MDPI, Basel, Switzerland. This article is an open access article distributed under the terms and conditions of the Creative Commons Attribution license (http://creativecommons.org/licenses/by/3.0/). 